\title{
O Eterno Retorno de Nietzsche como argumento do conto A biblioteca de Babel de Borges*
}

\author{
Henrique Aparecido Marson**
}

Resumo: Este trabalho visa mostrar que o conceito de Eterno Retorno de Nietzsche, em sua vertente cosmológica, foi utilizado por Borges como argumento do conto A biblioteca de Babel. Para tanto, a Poética da leitura será trazida à tona em conjunto com o conceito de situação filosófico-narrativa para subsidiar a investigação. Em seguida, o entendimento de Borges sobre o Eterno Retorno de Nietzsche terá lugar. Por fim, o conto será analisado para verificar nele os elementos que sustentam que o argumento de $A$ biblioteca de Babel é o conceito de Eterno Retorno de Nietzsche.

Palavras-chave: Borges, Eterno Retorno, Nietzsche, Situação filosófico-narrativa, Poética da leitura.

* As ideias expostas neste artigo estão desenvolvidas na dissertação de mestrado do autor - O Eterno Retorno e o amor fati de Nietzsche como situações filosófico-narrativas em quatro contos de Borges -, sobretudo no segundo capítulo, com orientação do Prof. Dr. Ivo da Silva Júnior, defendida na Escola de Filosofia, Letras e Ciências Humanas da Universidade Federal de São Paulo (UNIFESP), em 2017.

** Professor do Instituto Federal de São Paulo (IFSP), São Paulo, Brasil. Correio eletrônico: henrique.marson@gmail.com. 
Marson, H. A.

Para entender como Borges se apropria de textos alheios na realização de sua literatura e então poder buscar o Eterno Retorno de Nietzsche como argumento de A biblioteca de Babel, convém, antes de qualquer coisa, se ater à Poética da Leitura. Os escritos de Borges são todos frutos de suas leituras. Embora isso possa parecer óbvio à primeira vista, não o é, pois o escritor coloca explicitamente que, ao ler textos de outrem, se apropria deles através da leitura e a partir disso cria suas obras. Ou seja, a escrita borgiana nasce da leitura; todo livro de Borges encontra sua gênese no ato de ler. Isso fica evidente quando nos deparamos com o prólogo ao seu primeiro volume de contos, História universal da infâmia, no qual Borges escreve que as narrativas que compõem o livro "Derivam, creio, de minhas releituras de Stevenson e de Chesterton e também dos primeiros filmes de Von Stenberg e talvez de certa biografia de Evaristo Carriego" ". É, dessa maneira, por meio da leitura de certos escritores e livros, e da apreciação certos de filmes (que aqui se pode dizer que é uma espécie de leitura também) que Borges erige sua obra. Quando a História universal da infâmia é reeditada, ganha um novo prólogo que reitera o que se apresentou no primeiro. A origem do livro é creditada à leitura que Borges fez de contos já existentes e que a escrita é a adulteração, uma brincadeira que o escritor fez a partir da leitura deles: "[as narrativas do livro] São a irresponsável brincadeira de um tímido que não se animou a escrever contos e que se distraiu falsificando e deturpando (sem justificativa estética uma vez ou outra) histórias alheias"2. Porém, isso poderia ser entendido como uma contradição, pois como pode algo novo ser engendrado a partir de leituras de obras já existentes? No entanto, isso não é

\footnotetext{
1 Borges, 2012, p. 9.

2 Borges, 2012, p. 11-12.
}

$200 \mid$ Cad. Nietzsche, Guarulhos/Porto Seguro, v.39, n.3, p. 199-222, setembro/dezembro, 2018. 
O Eterno Retorno de Nietzsche como argumento do conto A biblioteca...

demérito, em verdade é algo original e é característico e decisivo da Poética da leitura ${ }^{3}$.

A crítica literária Beatriz Sarlo, ao escrever sobre Borges, diz que ele é "um escritor que, paradoxalmente, constrói sua originalidade por via da citação, da cópia, da reescrita de textos alheios, porque desde sempre pensa a escrita a partir da leitura"4. Causa espanto que Borges consiga obter algo novo a partir da cópia de textos que já existem. Borges leva a noção de apropriação de textos alheios a um paroxismo jamais visto até então, pois opera em seu labor criativo como um amanuense que, ao alinhavar em sua escrita elementos oriundos de outras obras, escreve um texto que não existia. E todo esse procedimento de apropriação do engenho estrangeiro empregado na criação literária borgiana se conforma na e pela leitura: aqui está a razão pela qual chamar a poética de Borges de Poética da leitura se mostra adequado à disciplina criativa que gera seus escritos.

A despeito da originalidade da Poética da leitura se estabelecer por meio da cópia, ela não se restringe à mera reprodução de outros textos, mas sim em uma espécie de renovação que a leitura realiza neles sem, contudo, que tais textos alterem sua substância e sem que deixem de ser os textos que efetivamente são. Há um teor de reprodução na Poética da leitura que é parte essencial dela. Contudo, aliado a isso há também algo novo que é produzido através da leitura, e é disto que eclode a novidade. Sendo assim, todo texto, desde sua primeira letra, está circunscrito a uma constelação de outros textos que, a um só tempo, se mantêm e se renovam no nascimento de um novo escrito. A literatura borgiana, destarte, lança mão de

3 Beatriz Sarlo também escreve em seu célebre ensaio sobre Borges que História universal da infâmia é o livro que "torna possível tudo o que virá na literatura de Borges; ali estão as operações que se expandirão nas décadas seguintes. Ali, nessas histórias de invenção alheia, está sua originalidade" (Sarlo, 2008, p. 93). Então é já nesse volume inaugural que se encontra a elaboração ficcional da disciplina poética que proporcionará a obra de Borges. Daí a proeminência desse livro que inicia, ao mesmo tempo em que consagra, a novidade da Poética da Leitura que Borges exercitará em seus textos.

4. Sarlo, 2008, p. 21.

Cad. Nietzsche, Guarulhos/Porto Seguro, v.39, n.3, p. 199-222, setembro/dezembro, 2018. 
Marson, H. A.

um procedimento que cria novidade pela reprodução, que escreve pela leitura, que renova pela repetição, pois toda escrita é, antes de mais nada, uma leitura de textos pré-existentes. Nesse sentido, podem ser lidas estas palavras do crítico literário Emir Monegal quando se refere à poética borgiana: "Toda história, todo texto é definitivamente original porque o ato de produção (= reprodução) não está na escritura, mas na leitura"5.

Ainda que a Poética da leitura já ilumine a chave da apropriação pela qual a literatura borgiana se faz, é o conceito de situação filosófico-narrativa que pode precisar o modo pelo qual Borges incorpora conceitos filosóficos para fins literários. A filosofia em Borges não surge como um adendo ou um adereço ao texto. $\mathrm{O}$ leitor que não teve contato com os escritos de Borges poderá pensar que a filosofia desabrocha em seus textos nas falas de personagens ou em alguma tirada do narrador, que é o que comumente ocorre. Porém, a filosofia se faz presente em Borges de uma forma mais profunda, ao ponto de conceitos filosóficos estruturarem as narrativas, ensaios, etc. Beatriz Sarlo, para equacionar o teor e a possibilidade de leitura filosófica que os textos borgianos contêm, cunhou o conceito seminal de situação filosófico-narrativa ${ }^{6}$. Com ele em mente, a filosofia nos textos de Borges se manifesta de modo mais nítido. Assim ela enuncia o conceito em voga:

situação filosófico-narrativa: uma ficção filosófica duplicada numa filosofia ficcional. As ideias não se apoderam da voz dos personagens nem se apresentam fora do desdobramento da trama, mas constituem sua verdadeira substância e a configuram de dentro. Se as ideias, em Borges, são indispensáveis para a emergência da ficção [...], as formas das ideias

5 Monegal, 1980, p. 71.

6 No texto de Sarlo, para destacar a eminência do conceito, o termo que o designa aparece grafado em itálico. Neste trabalho, o conceito aparecerá da mesma forma, com a mesma finalidade.

202 | Cad. Nietzsche, Guarulhos/Porto Seguro, v.39, n.3, p. 199-222, setembro/dezembro, 2018. 
O Eterno Retorno de Nietzsche como argumento do conto A biblioteca...

fornecem a trama do argumento. As ficções se fundam no exame de uma possibilidade intelectual apresentada como hipótese narrativa ${ }^{7}$.

Pode-se notar que o conceito de situação filosófico-narrativa oferece uma chave de leitura para elucidar como a filosofia integra os escritos literários de Borges. Ao destacar os pontos que definem o conceito, encontra-se em primeiro lugar que, em escritos de Borges, a filosofia constitui, por assim dizer, a própria fibra do texto. Longe de ser exterior à letra do texto, definir um personagem, ou ser comentários ou reflexões acerca dos fatos da narrativa, a filosofia é a sua substância mesma. É a partir de uma ideia filosófica que todos componentes da narrativa se organizam e operam, sejam eles personagens, narrador, tempo, ação, espaço, etc. Borges, nesse sentido, desdobra um pensamento filosófico em possibilidade narrativa, isto é, em possibilidade estética. Por consequência, em segundo lugar, o conceito filosófico é o argumento da narrativa. Ou seja, o alicerce da peça literária, a pedra fundamental que a sustenta, é uma ideia filosófica. Em terceiro lugar, a incorporação da filosofia na obra de Borges se dá sobremaneira pelo seu aspecto formal; quer dizer, ledo engano pensar que, a despeito da presença inequívoca da filosofia, ela não se mostrará em sua forma e conteúdo plenamente desvelados. Em vez disso, Borges traz a filosofia para seus textos através da forma das ideias; então o conteúdo de uma ideia filosófica é substituído por um material narrativo (que ainda assim conserva algo de filosófico). Porém, a ficção carrega a arquitetura filosófica que a forma das ideias lhe agrega. Por fim, em quarto lugar, Borges é um escritor que cria ficções a partir de possibilidades filosóficas: a filosofia não funciona como adorno dos textos, mas sim ela é a razão de ser dos relatos borgianos. Nessa esteira é que se pode adjetivar a ficção de Borges de filosófica; ou ainda se referir à sua literatura como uma filosofia ficcional. Ler os textos borgianos é se deparar com uma

7 Sarlo, 2008, p. 102-103.

Cad. Nietzsche, Guarulhos/Porto Seguro, v.39, n.3, p. 199-222, setembro/dezembro, 2018. 
Marson, H. A.

literatura que exprime ideias filosóficas e com ideias filosóficas que se convertem em uma literatura.

A partir das caracterizações da Poética da leitura por um lado, e da situação filosófico-narrativa por outro, já é possível divisar que ambas as noções estão coadunadas. A Poética da leitura exprime a ideia basilar da literatura borgiana, qual seja, a de que todo texto é composto de outros textos, de que um texto é fruto das leituras que o escritor empreendeu, ou mais radicalmente que toda escrita não passa da verbalização das leituras do autor. Sendo assim, a escrita nada mais é do que repetição, apropriação, colagem, dissimulação de outros textos concretizada pela leitura. Todo texto cunhado por Borges, portanto, aglutina aquilo que foi lido por ele: toda escrita é leitura. Já a situação filosófico-narrativa advoga que Borges se vale de uma questão filosófica para extrair dela possibilidades narrativas, desdobrando conceitos em ficções. O que realiza a mediação entre Poética da leitura e situação filosófico-narrativa é o fato de que Borges trata a filosofia explicitamente como uma expressão da literatura, isto é, entre filosofia a literatura não há traço distintivo. Com esses elementos a equação está montada. Resta agora resolvê-la. Para tanto, é necessário atentar para o denominador comum entre a Poética da leitura e a situação filosófico-narrativa. A Poética da leitura sustenta o procedimento de que um texto é resultado de outros textos, das leituras que o escritor empreendeu e que se convertem em escrita mediante um ato de criação-repetição; já a situação filosófico-narrativa estabelece que as ideias filosóficas são incorporadas à literatura de Borges, pois ele se serve delas para criar os argumentos de seus escritos; 0 ponto de convergência é que ambas as noções são de apropriação. A Poética da leitura opera isso num registro abrangente da literatura, ao passo que a situação filosófico-narrativa explica a deliberada atividade apropriadora de Borges em seara específica: a filosofia. Então, de certo modo, a situação filosófico-narrativa é como a filosofia é instituída como narrativa por Borges dentro do circuito da Poética

204 Cad. Nietzsche, Guarulhos/Porto Seguro, v.39, n.3, p. 199-222, setembro/dezembro, 2018. 
O Eterno Retorno de Nietzsche como argumento do conto A biblioteca...

da leitura; ela é uma parte da Poética da leitura, pois representa um dos mecanismos que fazem a concepção estética de apropriação empregada por Borges funcionar no que concerne à filosofia. Ambas servem de parâmetro para aventar a busca por elementos filosóficos nos textos de Borges, na medida em que esclarecem o caráter de incorporação por meio da leitura que define a obra de Borges, e, mais especificamente, a maneira que Borges lança mão de conceitos filosóficos para engendrar seus escritos.

Fica claro, então, segundo a Poética da leitura e a situação filosófico-narrativa, que Borges trabalha a filosofia em seus textos incorporando conceitos para trabalhar sua escrita. No que concerne à ficção, o escritor argentino se vale de conceitos filosóficos para determinar o argumento das narrativas. Em vista disso, pode-se divisar com mais precisão o intuito deste trabalho, qual seja, mostrar que o conto A biblioteca de Babel é uma peça de ficção cujo argumento é o conceito de Eterno Retorno de Nietzsche.

No conto em voga, Borges trabalha com a ideia da Biblioteca Total, ou seja, uma biblioteca que é tudo que existe, que se confunde com o universo. Logo no início do conto, essa metáfora fica evidente. Para evidenciar a relação que o argumento de A biblioteca de Babel possui com o pensamento de Nietzsche, pode-se buscar pistas no que o próprio Borges escreveu a respeito da gênese desse conto. No prólogo às Ficções se lê: "Não sou o primeiro autor da narrativa 'A biblioteca de Babel'; os curiosos de sua história e pré-história podem consultar certa página do número 59 de Sur, que registra os nomes heterogêneos de Leucipo e Lasswitz, de Lewis Carroll e Aristóteles"”. Borges não reivindica para si a originalidade do argumento do conto. $\mathrm{Na}$ verdade, o escritor argentino credita a outros nomes anteriores a ele a elaboração da ideia de uma Biblioteca Total.

O texto para o qual Borges remete a origem de $A$ biblioteca de Babel se intitula A Biblioteca Total. Borges destaca que a ideia da

8 Borges, 2007, p. 11.

Cad. Nietzsche, Guarulhos/Porto Seguro, v.39, n.3, p. 199-222, setembro/dezembro, 2018. 
Marson, H. A.

Biblioteca Total atravessa os séculos desde a antiguidade grega pensada por Demócrito e por Leucipo. Ela carrega elementos bastante característicos: a análise combinatória, o acaso e a tipografia sempre acompanham qualquer forma de imaginar a ideia da biblioteca absoluta. No entanto, vale destacar que, para Borges, a Biblioteca Total está intrinsecamente vinculada à doutrina do Eterno retorno: "Eu acrescentaria que é um avatar tipográfico dessa doutrina do Eterno Retorno que adotada pelos estóicos ou por Blanqui, pelos pitagóricos ou por Nietzsche, retorna eternamente"”. Nota-se que Borges enxerga em Nietzsche uma figura proeminente no que se refere à doutrina do Eterno Retorno. Também é possível observar que - se A biblioteca de Babel é um conto cuja ideia principal se encontra nesse texto da revista Sur, e essa ideia sempre se acha atrelada ao Eterno Retorno, e Borges vislumbra em Nietzsche um dos arautos da doutrina -, a narrativa em causa já possui um vínculo com o conceito de Eterno da filosofia de Nietzsche.

A Biblioteca Total - tema de A biblioteca de Babel - é animada pela ideia chave de que, a partir da combinação exaustiva de um número limitado de elementos, obtém-se a repetição dos resultados possíveis entre eles. Se a interação entre os elementos se perpetuar no tempo, as configurações se repetirão indefinidamente. Ou seja, essa biblioteca imaginada por Borges traria consigo o Eterno Retorno. Os elementos básicos podem ser palavras, átomos, caracteres, símbolos ortográficos, etc. Borges parece ter predileção de que as combinações sejam levadas a cabo entre os mais simples elementos ortográficos, que, segundo ele, totalizam vinte e cinco. Por meio da combinação entre essa quantidade limitada de elementos, poderia ser escrito tudo que é possível, seja qual for o idioma: "À base de simplificações [...] Kurd Lasswitz chega a vinte e cinco símbolos suficientes (vinte e duas letras, o espaço, o ponto, a vírgula) cujas variações com repetições

9 Borges, 1939 apud Monegal, 1987, p. 124).

206 Cad. Nietzsche, Guarulhos/Porto Seguro, v.39, n.3, p. 199-222, setembro/dezembro, 2018. 
O Eterno Retorno de Nietzsche como argumento do conto A biblioteca...

abarcam tudo que é dado expressar: em todas as línguas"10. Assim, percebe-se a ideia de que Tudo, absolutamente Tudo estaria na biblioteca cabal que abrigaria todas as variações possíveis entre os símbolos ortográficos e os repetiria infindavelmente. Se os elementos ortográficos são limitados em seu número, o caráter combinatório seria também limitado, pois o número de articulações possível entre eles não é infinito. É preciso acrescentar, se os elementos submetidos ao acaso não cessam de combinar-se entre si, a repetição se ergue como resultado inexorável, dando origem ao Eterno Retorno, nessa hipótese que Borges trabalha para explicar o que é a ideia da Biblioteca Total.

Então, essa biblioteca totalizante vinculada ao Eterno Retorno e a Nietzsche é o tema que Borges emprega em seu célebre conto A biblioteca de Babel. Elucidar como o escritor do Rio da Prata trabalha com uma noção extraída de Nietzsche para criar a narrativa fantástica, isto é, como a situação filosófico-narrativa enquanto força motriz do conto deriva do pensamento nietzschiano, passa por trazer à tona como Borges interpretava a filosofia de Nietzsche, sobretudo no que concerne ao tema do Eterno Retorno como característica fundamental da realidade. Pois, se a Biblioteca de Babel nada mais é do que o próprio universo, que, inequívoco, desemboca no Eterno Retorno do mesmo, é requerido entender como Nietzsche compreendia o universo - e o Eterno Retorno como marca inconfundível desse universo. Dito de outro modo, é preciso investigar como Borges interpretava a cosmologia nietzschiana.

Em um de seus ensaios, A doutrina dos ciclos, Borges elege como tema o Eterno Retorno. Nele, se acham elementos para entender como Borges interpretou a filosofia de Nietzsche no que se refere ao Eterno Retorno - traço fundamental de sua cosmologia. A doutrina que dá título ao ensaio, de acordo com Borges, foi chamada por Nietzsche, o mais recente "inventor" dela, justamente de Eterno Retorno. O escritor argentino diz que essa doutrina assume a seguinte forma:

10 Borges 1939 apud Monegal, 1987, p. 126.

Cad. Nietzsche, Guarulhos/Porto Seguro, v.39, n.3, p. 199-222, setembro/dezembro, 2018. 
Marson, H. A.

"O número de todos os átomos que compõem o mundo é, embora desmesurado, finito, e enquanto tal somente capaz de um número finito (embora também desmesurado) de permutações. Num tempo infinito, o número das permutações possíveis será atingido, e o universo se verá obrigado a repetir-se. Mais uma vez nascerás de um ventre, mais uma vez teu esqueleto crescerá, mais uma vez esta mesma página chegará a tuas mãos iguais, mais uma vez percorrerás todas as horas até chegar à tua incrível morte." Tal é a ordem habitual daquele argumento, começando pelo prelúdio insípido até chegar ao enorme desenlace ameaçador. É comum atribui-lo a Nietzsche ${ }^{11}$.

Distingue-se, de saída, que a doutrina do Eterno Retorno atribuída a Nietzsche se define através de duas linhas mestras que já se encontram na ideia da Biblioteca Total: a quantidade limitada de elementos e a combinação, igualmente limitada, que esses mesmos elementos podem originar. Envolto pelo tempo que não se esgota, o mundo chegaria inevitavelmente à sua repetição perpétua. Nesse trecho, no qual Borges descreve o sustentáculo crucial da tese nietzschiana do Eterno Retorno, percebe-se que é o mundo em seus caracteres e natureza fundamentais que é evidenciado. Ou seja, na medida em que o autor argentino trata da concepção de mundo consagrada a Nietzsche, que engendra o Eterno Retorno, é legítimo entender que Borges trata do que se pode nomear de cosmologia nietzschiana. Continuando a tratar da elaboração de Nietzsche para o Eterno Retorno, Borges exemplifica a doutrina. Ele imagina um universo composto apenas por dez átomos; e essa dezena pode se combinar através das maneiras pelas quais esses átomos podem ser dispostos, variando a ordem entre eles. Borges questiona: "Quantos estados diferentes esse mundo tem condições de conhecer, antes de um eterno retorno?", ao que ele mesmo responde recorrendo a uma exata operação combinatória, "Fácil responder: basta multiplicar $1 \times 2 \times 3 \times 4 \times 5 \times 6 \times 7 \times 8 \times 9 \times 10$, operação rigorosa que nos

11 Borges, 2010, p. 65.

208 Cad. Nietzsche, Guarulhos/Porto Seguro, v.39, n.3, p. 199-222, setembro/dezembro, 2018. 
O Eterno Retorno de Nietzsche como argumento do conto A biblioteca...

fornece 3.628.800"12 . Embora Borges fale de átomos para explicar a doutrina do Eterno Retorno em Nietzsche, a compreensão que ele possui do filósofo alemão é mais refinada. Nietzsche não trabalhou com a ideia de átomos. Ao invés disso, recusou-a e fez a opção pela energética $^{13}$. Nietzsche afirma, em um de seus fragmentos póstumos a tessitura do real como um conjunto limitado de forças: "Se o mundo pode ser pensado como grandeza determinada de força e como número determinado de centro de força - e toda outra representação permanece indeterminada e consequentemente inutilizável [...]" - assim como as próprias forças que são o mundo, afirma que as combinações entre elas são também limitadas: "disse se segue que ele tem de passar por um número calculável de combinações, no grande jogo de dados de sua existência" - no mesmo parágrafo o filósofo postula que infinito é o tempo: "Em um tempo infinito [...]" - e então, associado às forças limitadas, o tempo ilimitado resulta no Eterno Retorno: "cada combinação possível estaria alguma vez alcançada; mais ainda: estaria alcançada infinitas vezes" (Nachlass/FP 188814 [188], KSA 13.376). Borges parece ler o pensador de Röcken nesse sentido, quando afirma que "Nietzsche nega os átomos; para ele, a atomística não passava de um modelo do mundo feito exclusivamente para os olhos e para o entendimento aritmético... Para fundamentar sua tese, falou de uma força limitada, desenvolvendo-se no tempo infinito, mas incapaz de um número ilimitado de variações" "14.

O Eterno Retorno e Nietzsche surgem também em outro ensaio escrito por Borges. Trata-se do texto $O$ tempo circular. $\mathrm{O}$ autor diz na primeira frase do ensaio que costuma "eternamente retornar ao Eterno Retorno"15. O início da peça ensaística não traz

12 Borges, 2010, p. 64.

13 "Esta concepção traduz a opção que o filósofo faz pela energética. Posicionando-se contra o mecanicismo, ele substitui a hipótese da matéria pela da força" (Marton, 1990. p. 54).

14 Borges, 2010, p. 72.

15 Borges, 2010, p. 76.

Cad. Nietzsche, Guarulhos/Porto Seguro, v.39, n.3, p. 199-222, setembro/dezembro, 2018. 
esta afirmação à toa, porque Borges parece deixar claro com ela a importância e a constância da temática do Eterno Retorno que sua obra retém. Posto isso, o escritor diz que existem três formas fundamentais do Eterno Retorno. Uma delas é vinculada à filosofia nietzschiana. O Eterno Retorno elaborado por Nietzsche - que para Borges seria o mais recente inventor e divulgador - se assenta em "um princípio algébrico: a observação que um número $n$ de objetos [...] é incapaz de um número infinito de variações". Então, as forças limitadas não poderiam gerar um número ilimitado de interações. E isso, por conseguinte, é o suficiente para que o Eterno Retorno seja concretizado. Neste ensaio, dois ingredientes decisivos para o Eterno Retorno reaparecem: a limitação dos caracteres do mundo e das combinações possíveis entre eles. $\mathrm{O}$ que, por sua vez, reforça o fato de que Borges entende a doutrina elaborada por Nietzsche sobre essas duas bases.

Os elementos que configuram a cosmologia de Nietzsche entendida como doutrina do Eterno Retorno é a uma das substâncias principais do tema da Biblioteca Total, conforme aponta Borges. Então, convém elucidar com mais minúcia a concepção cosmológica de Nietzsche para identificar nela os pontos que Borges leva em conta e emprega em seu conto A biblioteca de Babel. Borges sustenta que o teor mais importante do pensamento nietzschiano se encontra nos escritos não publicados em vida pelo filósofo ${ }^{16}$. Ou seja, nos escritos de Nietzsche chamados de Fragmentos Póstumos. Num desses fragmentos Nietzsche se propõe a definir o que é o mundo:

Este mundo: uma monstruosidade de força, sem início, sem fim, uma firme, brônzea grandeza de força, que não se torna maior, nem menor, que não se consome, mas apenas se transmuda [...] força por toda parte, como jogo de

16 É neste artigo publicado na imprensa que Borges diz que os Fragmentos póstumos são a parte mais importante da obra de Nietzsche, pois ela abriga os verdadeiros pensamentos do filósofo: Algunos pareceres de Nietzsche. Disponível em: <http://www.lanacion.com.ar/214674-algunos-pareceres-denietzsche>. Acesso em: 20 dez. 2017.

$210 \mid$ Cad. Nietzsche, Guarulhos/Porto Seguro, v.39, n.3, p. 199-222, setembro/dezembro, 2018. 
O Eterno Retorno de Nietzsche como argumento do conto A biblioteca...

forças e ondas de força, ao mesmo tempo um e múltiplo, aqui se acumulando e ao mesmo tempo ali minguando, um mar de forças tempestuando e ondulando em si próprias, eternamente mudando, eternamente recorrentes, com descomunais anos de retorno, com uma vazante e enchente de suas configurações, partindo das mais simples às mais múltiplas, do mais quieto, mais rígido, mais frio, ao mais ardente, mais selvagem, mais contraditório consigo mesmo, e depois outra vez voltando da plenitude ao simples, do jogo de contradições de volta ao prazer da consonância, afirmando ainda a si próprio, nessa igualdade de suas trilhas e anos, abençoando a si próprio como aquilo que eternamente tem de retornar, como um vir-a-ser que não se conhece nenhuma saciedade, nenhum fastio, nenhum cansaço - [...] (Nachlass/FP 188538 [12], KSA 11.610)

Ora, à primeira vista já se observa que Nietzsche entende o mundo como uma multiplicidade finita de forças, e nesse sentido, coaduna com o que Borges diz a respeito do que é o mundo para o filósofo alemão. Não há nada de permanente nesse mundo de Nietzsche. Ao contrário, as forças não param de se combinar em perpétuo vir-a-ser. $\mathrm{O}$ movimento é contínuo, e as forças não cessam de se condicionarem entre si, assim geram as configurações que plasmam o mundo e se repetem no curso do tempo; ou seja, o mundo - ou as forças - retorna eternamente para o mesmo. Isto aponta à proposição de que o mundo é o Eterno Retorno do mesmo, a partir dessa concepção cosmológica que o assume como quantidade finita de forças em constante interrelação que repetem suas configurações no curso infinito do tempo. O mundo não possui início, tampouco fim. Ele é o eterno devir das forças. Desse modo, nesse parágrafo, é possível identificar os elementos que Borges sublinha como essenciais para o Eterno Retorno de estirpe nietzschiana. A saber: a quantidade limitada de forças; as configurações finitas que o mundo pode figurar a partir dessas forças; e o retorno sem trégua do mundo, pois as combinações entre as forças repercutem como repetição no decurso infinito do tempo. 
Marson, H. A.

Para Nietzsche, as forças são o universo. Frente à cosmologia nietzschiana é preciso ainda dar atenção para o fato de que essas forças não cessam de interagir porque se efetivam umas sobre as outras. As forças são esse efetivar-se mesmo. 0 mundo é resultante do dinamismo das forças. Diante disso, o mundo é eterno porque traz como característica fundamental o Eterno Retorno. "Se nada é a não ser vir-a-ser, então o mundo não teve início e nem terá fim" "17: moto perpetuo, as configurações limitadas oriundas das forças se repetem infinitas vezes. São duas ideias basilares sobre as quais repousa o pensamento nietzschiano: forças finitas; tempo infinito. A partir dessas premissas, Nietzsche extrai a tese do Eterno Retorno. Scarlett Marton apresenta do seguinte modo a vertente cosmológica do Eterno Retorno de Nietzsche ${ }^{\mathbf{1 8}}$ :

Finito, mas eterno: é o quanto basta para formular a doutrina do eterno retorno. Todos os dados são conhecidos: finitas são as forças, finito é o número de combinações entre elas, mas o mundo é eterno. Daí se segue que tudo já existiu e tudo tornará a existir. Se o número de estados por que passa o mundo é finito e se o tempo é infinito, todos os estados que hão de correr no futuro já ocorreram no passado ${ }^{19}$.

Parece ser nessa mesma direção que Borges compreende a doutrina do Eterno Retorno criada pelo autor do Zaratustra. Pois, conforme dito acima, o escritor avalia que Nietzsche trabalha com forças em número constante e com um tempo infinito, à medida que o mundo mesmo é eterno. Dessa soma insólita entre um princípio de ordem finita e outro de ordem infinita, eterna, o universo enquanto Eterno Retorno se impõe, sem começo e sem termo. Assim sendo,

17 Marton, 1990. p. 56.

18 Para maiores detalhes sobre a cosmologia de Nietzsche, cf. Marton, 1990: Nietzsche: das forças cósmicas aos valores humanos, especialmente o primeiro capítulo "A constituição cosmológica: vontade de potência, vida e forças".

19 Marton, 2009, p. 99.

212 | Cad. Nietzsche, Guarulhos/Porto Seguro, v.39, n.3, p. 199-222, setembro/dezembro, 2018. 
O Eterno Retorno de Nietzsche como argumento do conto A biblioteca...

de acordo com o que foi estabelecido até aqui, é possível depreender que a interpretação que Borges faz verifica que o Eterno Retorno em Nietzsche está intrinsecamente ligado às forças limitadas bem como às interações também limitadas entre elas no decorrer infinito do tempo, repetindo eternamente o mundo.

Essa interpretação do Eterno Retorno associado com a ideia da Biblioteca Total está no cerne da narrativa A biblioteca de Babel, ou seja, a situação filosófico-narrativa - que nada mais é do que o argumento central do conto, sua própria substância - se nutre de elementos que são obtidos por Borges da filosofia de Nietzsche. Se isso já se mostra com alguma precisão quando se volta o olhar para o artigo da Sur, que prefigura a temática central do conto, é na análise da letra própria narrativa, nos elementos que determinam seu argumento, que as evidências da filosofia nietzschiana podem ser encontradas, no que diz respeito à constituição mesma da peça literária.

A biblioteca, personagem principal, é descrita na primeira linha do texto como um avatar do universo, conforme se lê: "O universo (que outros chamam a Biblioteca) é composto de um número indefinido, e talvez infinito, de galerias hexagonais, com vastos poços de ventilação e balaustradas baixíssimas"20. O escritor argentino faz uma descrição minuciosa (sem abrir mão da concisão medular característica de seu estilo) da biblioteca. As galerias que a compõem são ligadas por corredores. Nesses corredores há dois cubículos, um de cada lado, um banheiro e um pequeno gabinete, e, como manifesto simbolismo da infinidade repetitiva da biblioteca, nos corredores da biblioteca há espelhos. De saída, o conto deixa claro que a biblioteca é o universo e traz à baila duas de suas características decisivas, ela (ou o universo) é infinita e repetitiva, já que a arquitetura da biblioteca é repleta de idênticas galerias.

20 Borges, 2007, p. 69.

Cad. Nietzsche, Guarulhos/Porto Seguro, v.39, n.3, p. 199-222, setembro/dezembro, 2018. 
Marson, H. A.

O foco narrativo do texto é em primeira pessoa. O narrador é um homem que viajou por inúmeros hexágonos em busca do Catálogo completo da biblioteca. Esse bibliotecário é taxativo: "Eu afirmo que a biblioteca é interminável"'21. Mais uma vez, a biblioteca como infinita é afirmada. A biblioteca sem dúvida é misteriosa e suscitou a sanha investigativa da curiosidade dos homens. Os diferentes livros, muitos deles sem o menor sentido, e a desordem imperativa disseminada pelos exemplares da biblioteca intrigaram os bibliotecários. Mais alguns parágrafos adiante no texto, o narrador diz que o enigma da natureza da biblioteca foi resolvido. Porém, antes de contar a solução, duas características da biblioteca são pontuadas categoricamente.

Tais caracteres são definidos como "axiomas" no âmbito do texto. Isto é, se são axiomas, são responsáveis por definir o modo pelo qual a biblioteca se estrutura; são, por assim dizer, o que essencialmente a biblioteca é. $\mathrm{O}$ axioma apresentado em primeiro lugar, novamente, vem para reforçar a eternidade da biblioteca, o que corresponde a afirmar, por conseguinte, a eternidade do real, do universo. A biblioteca é postulada com o signo da eternidade por Borges: "a Biblioteca existe ab aeterno. Dessa verdade cujo corolário imediato é a eternidade futura do mundo, nenhuma mente razoável pode duvidar". Outro axioma da biblioteca apresentado no conto esclarece que "o número de símbolos ortográficos é vinte e cinco". Esses vinte e cinco símbolos são os mesmos que Borges tratou no texto A biblioteca total: "A pontuação foi limitada à vírgula e ao ponto. Esses dois signos, o espaço e as vinte duas letras do alfabeto são os vinte e cinco símbolos suficientes que o desconhecido enumera"22. Tal axioma nada mais é do que a afirmação de que os elementos constitutivos de toda a biblioteca são limitados em seu número. Afinal, é desses elementos mais nucleares se combinando mútua e incessantemente que surgem os volumes que preenchem as

21 Borges, 2007, p. 70.

22 Borges, 2007, p. 71.

214 Cad. Nietzsche, Guarulhos/Porto Seguro, v.39, n.3, p. 199-222, setembro/dezembro, 2018. 
O Eterno Retorno de Nietzsche como argumento do conto A biblioteca...

prateleiras das galerias hexagonais, quer dizer, que surge a biblioteca (ou o universo).

É relativamente fácil observar que os axiomas estruturantes da biblioteca são semelhantes ao Eterno Retorno de Nietzsche. O texto de ficção fornece vários indícios que sustentam com alguma solidez a sua ligação com a filosofia do Eterno Retorno do filósofo alemão. Obviamente isto não é mera coincidência. A biblioteca de Babel é um texto que trabalha o tema da Biblioteca Total. Esta, por seu turno, é uma ideia que Borges associa com o Eterno Retorno, e ele encontra em Nietzsche um dos principais elaboradores dessa doutrina. Foram esses postulados da biblioteca que propiciaram, assim como os postulados acerca do mundo permitiram a Nietzsche, desvendar a natureza da biblioteca/universo. De acordo com a narrativa, um bibliotecário pensador se deparou com um livro cujo idioma e conteúdo eram indecifráveis. Porém, o enigma é desvendado; nada mais é do que um livro escrito em idioma híbrido, e seu conteúdo é matemático: “Antes de um século puderam estabelecer o idioma: um dialeto samoiedolituano do guarani, com inflexões do árabe clássico. Também se decifrou o conteúdo: noções de análise combinatória. Ilustradas por exemplos de variações com repetições infinitas" "23. Aqui é importante sublinhar que Borges já havia tratado em um de seus ensaios o Eterno Retorno de Nietzsche através do recurso da combinatória, conforme ficou esclarecido acima. Neste trecho do conto também fica evidente que esse livro que o bibliotecário encontra e decifra já prefigura a natureza da Biblioteca Total e é chave para trazer à tona o que é a biblioteca/universo no âmbito interno da narrativa: os elementos combinam-se e repetem-se infinitamente, característica candente da maneira nietzschiana de elaborar Eterno Retorno que é o universo. Ou seja, é com alguma segurança que se pode depreender que Borges alude ao pensamento de Nietzsche nesse pequeno excerto do conto que está em análise, no qual o livro que trata da análise

23 Borges, 2007, p. 73.

Cad. Nietzsche, Guarulhos/Porto Seguro, v.39, n.3, p. 199-222, setembro/dezembro, 2018. 
Marson, H. A.

combinatória e de repetição infinita aparece; além disso, já é, em alguma medida, possível observar que a natureza da biblioteca, ou do universo, nesse texto se sustenta a partir de motivos filosóficos originados da obra de Nietzsche.

O escrutínio da peça literária de Borges, direcionada aos elementos que compõe a situação filosófico-narrativa, manifesta mais indícios da presença da elaboração cosmológica de Nietzsche na construção do argumento do conto. É notório que Borges define o Eterno Retorno a partir de dois pilares fundamentais: elementos finitos; elemento infinito. Esses dois pilares aparecem n'A biblioteca de Babel. Conforme o teor do texto assevera, o bibliotecário pensador, que desvendou o livro confuso, e, a partir dele, conseguiu de modo contundente também lançar luz sobre os aspectos essenciais da biblioteca:

Esse pensador observou que todos os livros, por diversos que sejam, constam de elementos iguais: o espaço, o ponto, a vírgula, as vinte duas letras do alfabeto. [...] Dessas premissas irrefutáveis deduziu que a biblioteca é total e que suas prateleiras registram todas as possíveis combinações dos vinte e tantos símbolos ortográficos (número, ainda que vastíssimo, não infinito), ou seja, tudo o que é dado expressar: em todos os idiomas. Tudo: a história minuciosa do futuro, as autobiografias dos arcanos, o catálogo fiel da Biblioteca, o comentário desse evangelho, o relato verídico de tua morte, a versão de cada livro em todas as línguas, as interpolações de cada livro em todos os livros, o tratado que Beda pôde escrever (e não escreveu) sobre a mitologia dos saxões, os livros perdidos de Tácito ${ }^{24}$.

Então todos os volumes que a Biblioteca Total abriga são constituídos por um número limitado de elementos - pouco mais de duas dezenas de símbolos ortográficos. Esses símbolos geram combinações entre si, que são o conteúdo que os livros da biblioteca encerram, que são a própria biblioteca e são também o universo, à medida que biblioteca e universo são o mesmo. Aqui se vê,

24 Borges, 2007, p. 73.

216 Cad. Nietzsche, Guarulhos/Porto Seguro, v.39, n.3, p. 199-222, setembro/dezembro, 2018. 
O Eterno Retorno de Nietzsche como argumento do conto A biblioteca...

possivelmente, que essas características se associam com traços marcantes da cosmologia de Nietzsche. Pois, o filósofo entende o mundo como um conjunto de forças, estas em quantidade, ainda que imensurável, limitada. As forças em constante vir a ser interagem e geram combinações entre elas. Esse jogo de energia é, segundo o pensamento de Nietzsche, o mundo. O Universo é força e nada mais. Tudo que é o mundo não passa de interação entre as forças que formam a realidade mesma. Pode-se entender, portanto, que às forças da filosofia de Nietzsche correspondem os vinte e cinco símbolos ortográficos. Ambos - o elemento da cosmologia filosófica e o elemento da peça de ficção - são limitados em seu número, são o estribo fundamental da realidade, se combinam mútua e limitadamente e plasmam tudo o que existe: o universo e a biblioteca, respectivamente. A biblioteca no conto de Borges é o universo porque é concebida a partir da apropriação da concepção de mundo de Nietzsche. Embebida e determinada pela cosmologia nietzschiana em seu argumento, $A$ biblioteca de Babel não poderia abarcar qualquer outra coisa que não fosse a plenitude da realidade, repita-se, o universo.

A presença da concepção de mundo do filósofo alemão na narrativa de Borges, ainda determina outro aspecto do conto, quiçá o principal e que permite associar seu argumento ao pensamento de Nietzsche: o Eterno Retorno do mesmo. O filósofo é categórico em sua cosmologia, pois a engenharia dela que conjuga a um só tempo o finito e o infinito deságua inevitavelmente no Eterno Retorno. Para Nietzsche, o mundo necessariamente evoca o Eterno Retorno do mesmo. Tão eterno quanto o mundo, que não teve início e tampouco terá fim, é a norma do curso circular do universo que engendra repetição; o Eterno Retorno não encontra começo ou término, ele é tão constante quanto o próprio universo, pois é a realidade mesma. Portanto, toda e qualquer possibilidade que o mundo admite, enquanto jogo de forças, não se dá alheia ao Eterno Retorno. Ao invés disso, 
Marson, H. A.

tudo o que existe é enquadrado e submetido à lei máxima do universo, à lei do eterno curso circular de todas as coisas.

Assim como a concepção de mundo de Nietzsche traz consigo o Eterno Retorno do mesmo, a biblioteca absoluta borgiana, ao se nutrir das mesmas ideias, resulta no Eterno Retorno do mesmo. Uma vez que a base de sustentação da Biblioteca Total tematizada no conto em voga é a mesma da cosmologia de Nietzsche, pode-se aventar a possibilidade de o Eterno Retorno surgir da narrativa. Afinal, se os pressupostos que lastreiam a cosmologia de Nietzsche marcham com precisão e inevitabilidade em direção ao Eterno Retorno, na biblioteca, calcada nos mesmos pressupostos, o resultado não poderia ser diferente. Assim como o mundo, a biblioteca é infinita. Infinita no sentido de não possuir termo. É preciso guardar observância para que o infinito não seja compreendido aqui como sinônimo de ilimitado, no sentido de que o mundo ou a biblioteca pudessem criar novos estados continuamente. Não é esse o caso. Porque a biblioteca é infinita devido à sua circularidade, que é denominada no texto como periodicidade. Ou seja, a biblioteca é infinita através da repetição. O final de $A$ biblioteca de Babel caracteriza de maneira, embora insinuante, bastante clara a eternidade da Biblioteca Total engendrada pela repetição infinita, constante da própria biblioteca:

Acabo de escrever infinita. Não introduzi esse adjetivo por um hábito retórico; digo que não é ilógico pensar que o mundo é infinito. Os que o julgam limitado postulam que em lugares remotos os corredores e hexágonos podem inconcebivelmente cessar - o que é absurdo. Os que imaginam sem limites esquecem que não é ilimitado o número de livros. Eu me atrevo a insinuar esta solução do antigo problema: "A Biblioteca é ilimitada e periódica". Se um viajante eterno a atravessasse em qualquer direção, comprovaria ao cabo de séculos que os mesmos volumes se repetem na mesma desordem (que, repetida, seria uma ordem: a Ordem) ${ }^{25}$.

25 Borges, 2007, p. 78-79.

218 Cad. Nietzsche, Guarulhos/Porto Seguro, v.39, n.3, p. 199-222, setembro/dezembro, 2018. 
O Eterno Retorno de Nietzsche como argumento do conto A biblioteca...

Para Nietzsche, o real é um conjunto de forças; ele também afirma que infinito é o tempo. Combinados, esses dois fatores trazem o cosmos como repetição. Ou seja, como retorno do mesmo. Tudo retorna na inalterada ordem e sequência, conforme escreve o filósofo no Fragmento póstumo:

entre cada combinação e retorno todas as cominações ainda possíveis teriam de estar transcorridas e cada uma dessas combinações condiciona a sequência inteira das combinações da mesma série, com isso estaria provado um curso circular de séries absolutamente idênticas: o mundo como curso circular que infinitas vezes já se repetiu e que joga seu jogo in infinitum (Nachlass/FP 1888 14 [188], KSA 13.376)

Borges parece ir pela mesma vereda em sua narrativa. Ele a postula como um conjunto limitado de elementos que são representados, no conto $A$ biblioteca de Babel, pelos vinte cinco símbolos ortográficos, que se combinam mutuamente formando os livros. No entanto tais combinações são limitadas, o que gera volumes de livros em quantidade limitada, e isso é perpetrado por uma repetição periódica, que traz os mesmos volumes de volta na mesma ordem e sequência. Borges então arremata o conto com o Eterno Retorno do mesmo como característica decisiva da biblioteca. Ela é eterna, e é assim porque é periódica, isto é, porque se repete indefinidamente. Certamente, a conclusão da narrativa não poderia ser outra que não a mesma da cosmologia de Nietzsche: Eterno Retorno do mesmo, uma vez que o argumento da narrativa de Borges consiste no conceito da filosofia de Nietzsche. Então, arraigada nas ideias cosmológicas de Nietzsche, que conduzem à eterna repetição de todas as coisas do cosmos, a Biblioteca Total - metáfora do universo - se inscreve na mesma forma circular da concepção de mundo do Eterno Retorno do mesmo ao repetir os mesmos livros, as idênticas combinações dos símbolos ortográficos infinitamente. 
Marson, H. A.

É possível pensar, doravante, que a quantidade limitada de força equivale aos vinte e cinco símbolos ortográficos. Estes, bem como as forças, combinam-se entre si. No entanto, tais combinações são também limitadas em sua quantidade. Outra evidência que atesta similitude entre a filosofia de Nietzsche e a ficção levada a cabo por Borges desponta no fato de que a Biblioteca, assim como o mundo, é eterna porque se repete. Eternidade se dá sob a condição da repetição sem fim. Uma vez que as possibilidades que biblioteca e do mundo podem configurar como realidades são finitas, e esses (biblioteca ou universo) perduram no tempo infinito, ambos estão como que condenados à repetição das mesmas permutações na mesma ordem e sequência para sempre. Portanto, a concepção de mundo de Nietzsche e a narrativa borgiana estão irmanadas pelos mesmos elementos constitutivos - finitos e infinitos - e, exatamente por isso, ambas resultam e se colocam sob a égide do Eterno Retorno do mesmo.

Pode-se dizer, à guisa de conclusão, que a narrativa se dá dessa forma por causa da disciplina criativa adotada por Borges. A Poética da leitura - aquela que se nutre de textos outros para a confecção do objeto de arte, aquela que determina que o texto nada mais é do que a expressão de uma leitura de outros textos, aquela que, finalmente, estabelece que toda literatura está fundada em primeira e última instância na atividade leitora -, tomada como princípio, permite inferir que, se Borges foi leitor de Nietzsche - e ele foi -, caracteres da filosofia nietzschiana certamente foram incorporadas por Borges em sua obra. Daí a concepção de mundo do filósofo ser mote principal da narrativa em questão. Outro ponto que é exemplificado pelo presente trabalho é o fato de que Borges lida profundamente com a filosofia em sua literatura. É com centralidade que a obra de Borges coloca a filosofia; arte e pensamento têm um elo insolúvel nos textos do escritor argentino ${ }^{\mathbf{2 6}}$. A filosofia nietzschiana, mais precisamente

26 Cf. Arrigucci Jr., 1999, p. 278-288.

220 | Cad. Nietzsche, Guarulhos/Porto Seguro, v.39, n.3, p. 199-222, setembro/dezembro, 2018. 
O Eterno Retorno de Nietzsche como argumento do conto A biblioteca...

sua cosmologia, é o argumento do conto, logo a biblioteca que detém completa proeminência no texto se ergue a partir de uma arquitetura ficcional praticamente ad verbum baseada na concepção de mundo de Nietzsche, pois os elementos que configuram a biblioteca são obtidos ou criados a partir do pensamento do filósofo. Em outras palavras, o argumento do conto é constituído a partir da forma de um conceito cuja origem é identificada na maneira pela qual Nietzsche entende o universo como Eterno Retorno do mesmo. O pensamento nietzschiano mostra-se como a própria substância da narrativa, determinando intrinsecamente o conto como uma ficção filosófica. O conto submetido ao escrutínio é a ficcionalização de um conceito filosófico. É uma noção originalmente filosófica convertida em peça artística de modalidade literária. Ao fim e ao cabo, diante do exposto, pode-se dizer que, em A biblioteca de Babel, a vertente cosmológica do Eterno Retorno de Nietzsche aparece enquanto situação filosóficonarrativa, porque é o argumento do conto.

\footnotetext{
Abstratet: This work aims to show the concept of Eternal Return of Nietzsche, in its cosmological version, it was used by Borges as argument of the story The Library of Babel. Therefore, the Poetics of reading will be brought up along with its connection with the concept of the philosophical-narrative situation to subsidize the research. Then, the understanding of Borges about the Eternal Return of Nietzsche will be discussed. Finally, the story will be analyzed in order to check on it the elements that show that the argument of The Library of Babel is Nietzsche's concept of Eternal Return. Keywords: Borges, Eternal Return, Nietzsche, Philosophicalnarrative situation, Poetics of reading.
} 
Marson, H. A.

\section{Referências bibliográficas}

ARRIGUCCI JR, D. Borges ou do conto filosófico. In: ARRIGUCCI JR, D. Outros achados e perdidos - ensaios sobre literatura e experiência. São Paulo: Companhia das Letras, 1999.

BORGES, J. L. Ficções. São Paulo: Companhia das Letras, 2007.

. História da eternidade. São Paulo: Companhia das Letras, 2010.

. História universal da infâmia. São Paulo: Companhia das Letras, 2012.

MARTON, S. Nietzsche, das forças cósmicas aos valores humanos. São Paulo: Brasiliense, 1990.

. Extravagâncias: ensaios sobre a filosofia de Nietzsche. São Paulo: Discurso Editorial, 2009.

MONEGAL, E. R. Borges: uma poética da leitura. São Paulo: Perspectiva, 1980. . Borges por Borges. Porto Alegre: L\&PM, 1987.

NIETZSCHE, F. Obras incompletas. 2 ed. Trad. Rubens Rodrigues Torres Filho. São Paulo: Abril Cultural, 1978.

. Sämtliche Werke. Kritische Studienausgabe (KSA). Organizada por Giorgio Colli e Mazzino Montinari. Berlim: Walter de Gruyter, 1988. 15 vols.

SARLO, B. Borges, um escritor na periferia. São Paulo: Iluminuras, 2008.

Artigo recebido para publicação em 13/01/2018

Artigo aceito para publicação em 18/10/2018

222 | Cad. Nietzsche, Guarulhos/Porto Seguro, v.39, n.3, p. 199-222, setembro/dezembro, 2018. 